\title{
Blended Counselling as a Solution for the Development of Mental Health and Understanding Herd immunity for Society
}

\author{
Agus Supriyanto $^{1}$, Mulawarman ${ }^{2}$, Soesanto $^{3}$, Dwi Puji Yuwono Sugiharto ${ }^{4}$, Sri Hartini ${ }^{5}$ \\ 1,2,3,4 Universitas Negeri Semarang, Indonesia \\ ${ }^{5}$ Universitas Ahmad Dahlan, Indonesia \\ Email Address: mulawarman@mail.unnes.ac.id
}

Submitted : 29-08-2021, Revised : 26-09-2021, Accepted : 17-11-2021

\begin{abstract}
The Covid-19 (C-19) pandemic has had a significant impact on the mental health of individuals around the world. Society needs an end to the C-19 pandemic through the state of its herd immunity (HI). Significant roles counsellors in developing herd immunity and then mental health with a blended counselling strategy. This paper aims to design a counselling mix to create mental health and an understanding of herd immunity in the community. The results of the community data are fear, anxiety, anger, insomnia, and prolonged stress as a form of mental health of the community because it is socially and economically constrained. The length of time for the formation of herd immunity to prevent the C-19 pandemic is because people are worried and doubtful about vaccinations so that vaccines appear or do not trust. Significant roles counsellors in the formation of mental health through integrated counselling The implementation of face-to-face and online counselling allows the community to be more flexible and intensive according to conditions in the construction of mental health $\mathrm{C}-19$ pandemic condition and post-C-19 preparations. Blended counselling as an intervention for the community in understanding herd immunity as a form supported the end of the $\mathrm{C}-19$ pandemic. Integrated counselling requires the joint efforts of various relevant organizations for the science and practice of psychotherapy, psychiatry, and counsellor.
\end{abstract}

Keywords: Blended counselling; Herd immunity; Mental health;

\section{Introduction}

The coronavirus since 2020 in Indonesia or throughout the world impacts the economy, work, and education. A pandemic arises because of an epidemic that spreads globally due to the coronavirus's effortless transmission (Grennan, 2019). This condition causes corona phobia and mental health complications (Biondi \& Iannitelli, 2020; Rahman et al., 2021). Complications of mental health problems arise due to self-restriction and locking of specific areas that impact depression and anxiety conditions (Marelli et al., 2021), especially for all people in Indonesia. The state of the community C-19 pandemic condition wasn't perfect from an academic and health perspective.

The research shows negative stigma about the C-19 pandemic through social media can affect psychological risk factors and risk individual mental health (Holingue et al., 2020). The fear of the coronavirus harms the health of individuals, especially in vulnerable groups. The C19 pandemic has affected the education system and curriculum (Daniel, 2020; Toquero, 2020), although the advancement of digital education (Sonia \& Kumar, 2020) is increasingly popular with online learning or e-learning (Krishnamurthy, 2020; Rashid \& Yadav, 2020). The research shows that today's learning process is enough with Android as an advance in digital technology (Nashruddin \& Tanasy, 2021).

Advances in digital technology in the field of education C-19 pandemic condition have also had adverse effects. The negative impact if the C-19 pandemic does not end soon in education is the dropout rate of students and the quality of learning from teachers and students because students experience learning disorders (Bank, 2020; Rogers \& Sabarwal, 2020). Although it has a negative impact, educational progress is growing through the digitalization of education. Professional teachers can carry out an extraordinary educational process, although the interaction of teachers and students or lecturers and students is limited. 
Counsellors play a role in helping to overcome problems faced by students, especially counselling services in the digital era and the conditions of the C-19 pandemic.

Over time, from 2020 to 2021, herd immunity has emerged. Herd immunity will arise if most humans are immune to the virus, impacting the outbreak's end (Schaeffer et al., 2021). This condition follows that many social interactions in education, work, and social activities have appeared. Although the spread of C-19 is continually increasing, most people are recovering and recovering, or herd immunity. Herd immunity appears in two ways: vaccination or natural infection from the spread of C-19 to the population (Xia et al., 2020). Public understanding of herd immunity must be socialization. Counsellors have a role in developing an understanding of herd immunity, and there must be a solution for people with primitive thinking.

Counsellors have the ability in counselling services. Knowledge, cultural skills, basic attitudes, basic communication skills, and basic attitudes of counsellors are the main elements of counsellor competence in counselling services (Setiyowati et al., 2019). Counsellors in the C-19 or post-C-19 pandemic have innovations in counselling services, one of the counselling service strategies through blended counselling in the future. Blended counselling combines face-to-face and online counselling synchronously and asynchronously (Pyrstöjärvi \& Saramäki, 2011). This study aims to conceptualize blended counselling services to help develop mental health and increase understanding of herd immunity in Indonesian society.

\section{Methods}

This study has three independent variables to form the basic concept of intervention supporting counselling services. The three variables in this research include (a) the mental health condition of the community C-19 pandemic condition, (b) an understanding of the community's herd immunity, and (c) the blended counselling model. The literature review in this study helps design blended counselling that aims to develop mental health and understanding of community herd immunity. The basis of the literature review is the problem of the mental health condition of the Indonesian people or the world. Then the emergence of herd immunity as a solution to end the $\mathrm{C}-19$ pandemic. There is also the role of counsellors in online counselling services that are less supportive of C-19 pandemic condition, so blended counselling is an alternative for counsellors. These various problems require blended counselling that counsellors can implement to develop mental health and understanding of community herd immunity from diverse, relevant literature.

The criteria for the literature in this study are national journals and international journals, with supporting books. The collected data is analyzed to find the implementation concept of blended counselling and ways of developing mental health and understanding herd immunity through blended counselling. The final data results will be interpreted and discussed as qualitative. Documents in the form of books, national journals, and international journals relevant to the community's mental health condition C-19 pandemic condition, understanding community herd immunity, and blended counselling models. We were developing mental health and understanding herd immunity through blended counselling. The final data results will be interpreted and discussed as qualitative. Qualitatively analysed documents through four steps of analysis. The four steps of research in the literature review include data reduction from appropriate books and journals. Will interpret the results of data reduction with relevant data, then concluded by the researcher. The last is data verification that finds theories supporting blended counselling implementation for mental health development and understanding herd immunity in society. 


\section{Results and Discussion}

Data's about the public mental health of society through relevant journals published in the 2021 year. Then data collection on herd immunity in books and periodicals published in the 2021 year. The concept of blended counselling in books and journals published in 20102021 years. These data are reduced and presented through tables. Then the data is interpreted through discussions that are supported and compared through various scientific researches.

\section{Mental Health of the Community in the C-19 Pandemic Condition}

The C-19 pandemic has a direct impact on individuals mental health. Mental health problems are urgent to be analyzed and create strategies in counselling services by counsellors. The facts of mental health problems need to be studied more deeply. The following are supporting data related to the mental health condition of the community with the influencing factors resulting from the $\mathrm{C}-19$ pandemic, then recommendations for mental health development solutions.

Table 1. Community Mental Health C-19 Pandemic Condition

\begin{tabular}{|c|c|c|}
\hline Topic & Description & Author \\
\hline $\begin{array}{c}\text { Community Mental } \\
\text { Health Conditions } \\
\text { Factors Causing Public }\end{array}$ & $\begin{array}{l}\text { The emergence of fear, anxiety, } \\
\text { insomnia, anger, denial, racism, and } \\
\text { long-term stress in parents, children, } \\
\text { workers, and vulnerable groups from } \\
\text { stigma through social media or regional } \\
\text { isolation from a policy. }\end{array}$ & $\begin{array}{l}\text { Gillard et al. (2021); } \\
\text { Kumar \& Nayar } \\
(2021) ; \text { Lestari \& } \\
\text { Setyawan (2021); } \\
\text { Roy et al. (2021) }\end{array}$ \\
\hline $\begin{array}{l}\text { Mental Health Problems } \\
\text { in the C-19 pandemic } \\
\text { condition }\end{array}$ & $\begin{array}{l}\text { b. Emotional loneliness in parents arises } \\
\text { because of social isolation policies, } \\
\text { affecting mental health, so they need } \\
\text { friends. } \\
\text { c. Parents have a higher stress level, then } \\
\text { need support from parents and children. }\end{array}$ & $\begin{array}{l}\text { Alonzo et al. (2021); } \\
\text { Rains et al. (2021); } \\
\text { Van Tilburg et al. } \\
\text { (2021) }\end{array}$ \\
\hline $\begin{array}{l}\text { Advanced Interventions } \\
\text { for Mental Health } \\
\text { Development }\end{array}$ & $\begin{array}{l}\text { The mental health of individuals or } \\
\text { communities arises because of economic and } \\
\text { social factors. Economic factors are due to } \\
\text { the poor economic conditions of the } \\
\text { community and social isolation. } \\
\text { a. Integration of remote and face-to-face }\end{array}$ & $\begin{array}{l}\text { Mukherjee et al. } \\
\text { (2021) }\end{array}$ \\
\hline \multirow[t]{3}{*}{$\begin{array}{l}\text { Community Mental } \\
\text { Health Conditions }\end{array}$} & $\begin{array}{l}\text { interventions into community mental } \\
\text { health. } \\
\text { b. Community counselling interventions for } \\
\text { mental health development } \\
\text { c. Online counselling services as mental } \\
\text { health support. }\end{array}$ & $\begin{array}{l}\text { Kopelovich et al., } \\
(2021) ; \text { Kumar \& } \\
\text { Nayar (2021); } \\
\text { Lestari \& Setyawan } \\
(2021)\end{array}$ \\
\hline & $\begin{array}{l}\text { d. Positive relationship and socioemotional } \\
\text { support as factors supporting mental } \\
\text { health. }\end{array}$ & Li et al. (2021) \\
\hline & $\begin{array}{l}\text { e. Therapeutic relationships are not only in } \\
\text { the environment but also in the hospital. }\end{array}$ & Johnson et al. (2021) \\
\hline
\end{tabular}

The conclusion from the data results is that the C-19 pandemic impacted the community. Mental health social problems in the C-19 pandemic condition appear in the emergence of fear, anxiety, insomnia, anger, denial, racism, and long-term stress. All mental health problems occur in all elements of society from children, parents, workers, students, and 
vulnerable groups who have comorbidities. All of these conditions are because of news from social media. The community's mental health is also affected by the world government's policy of isolation to prevent $\mathrm{C}-19$. The contributing factors of all mental health problems are urgent to help because of poor economic issues. In addition to economic factors that are affected throughout the world, their governments in all countries limit.

Mental health problems are urgent to be assisted by counsellors through counselling services. Counselling services through face-to-face and virtual counselling need to combine for mental health development. Counselling services by counsellors must create positive and therapeutic relationships, thereby generating socio-emotional support in the development of community mental health. In addition, the need for intervention on individuals in hospitals as assistance by counsellors in counselling services.

\section{Herd Immunity}

People need to understand the condition of herd immunity as a form of solution to the end of the C-19 pandemic. Qualitative studies through in-depth analysis of the situation of herd immunity need comprehensive research - the need for answers related to in-depth studies with various relevant sources. The following is a study of the formation of herd immunity in the community, the effects of vaccination, and solutions for developing an understanding of herd immunity in the community.

Table 2. Community Herd Immunity C-19 pandemic condition

\begin{tabular}{|c|c|c|}
\hline Topic & Description & Author \\
\hline \multirow{3}{*}{$\begin{array}{l}\text { Formation of } \\
\text { Herd Immunity } \\
\text { in Society } \\
\text { Vaccination } \\
\text { Effect }\end{array}$} & $\begin{array}{l}\text { a. Herd immunity arises through vaccinations that } \\
\text { are carried out en masse regardless of age. }\end{array}$ & $\begin{array}{l}\text { Barker et al., (2021); } \\
\text { Dassarma et al., } \\
\text { (2021); MacIntyre et } \\
\text { al., (2021) }\end{array}$ \\
\hline & $\begin{array}{l}\text { b. Herd immunity in individuals arises when } \\
\text { individuals have contracted the coronavirus and } \\
\text { recovered from C-19, as well as from mass } \\
\text { vaccination. }\end{array}$ & $\begin{array}{l}\text { Garg et al., (2021); } \\
\text { Setiawan et al., } \\
\text { (2021) }\end{array}$ \\
\hline & $\begin{array}{l}\text { c. The end of the } \mathrm{C}-19 \text { pandemic is if the } \\
\text { percentage of herd immunity is } 60 \%-70 \% \text { of the } \\
\text { total population in a country or region from } \\
\text { various types of vaccines. }\end{array}$ & $\begin{array}{l}\text { Gumel et al., (2021; } \\
\text { Zaidi et al., (2021) }\end{array}$ \\
\hline $\begin{array}{l}\text { Formation of } \\
\text { Herd Immunity } \\
\text { in Society }\end{array}$ & $\begin{array}{l}\text { Vaccination of individuals still allows individuals to } \\
\text { contract the coronavirus, and then immunity has a } \\
\text { waiting period. }\end{array}$ & Pennington, (2021) \\
\hline $\begin{array}{l}\text { Vaccination } \\
\text { Effect }\end{array}$ & $\begin{array}{l}\text { a. Doubts about vaccination affect the longer the C- } \\
19 \text { pandemic due to lack of education, so the risk } \\
\text { of delay and rejection of vaccines is on the } \\
\text { individual's health. } \\
\text { b. The need to raise an understanding of } \\
\text { vaccination, so it is necessary to increase the } \\
\text { intention, knowledge, belief, and motivation } \\
\text { towards vaccines, then empathy towards } \\
\text { vulnerable groups. } \\
\text { c. Worries about vaccines and misinformation } \\
\text { about vaccines are barriers to mass vaccination } \\
\text { processes and obstacles to herd immunity. }\end{array}$ & $\begin{array}{l}\text { Al-Amer et al., } \\
\text { (2021); Bliss et al., } \\
\text { (2021); Dhama et } \\
\text { al., (2021); Hildreth } \\
\text { \& Alcendor, (2021); } \\
\text { Pfattheicher et al., } \\
\text { (2021); Wiysonge et } \\
\text { al., (2021) }\end{array}$ \\
\hline
\end{tabular}




\begin{tabular}{ccc}
\hline Topic & \multicolumn{1}{c}{ Description } & Author \\
\hline & d. & $\begin{array}{l}\text { Involvement of all multisectoral components so } \\
\text { that the community implements vaccines (public } \\
\text { trust in vaccines). }\end{array}$ \\
\hline
\end{tabular}

The results of various data analyses raise the concept that herd immunity is formed in two ways through mass vaccination regardless of age and in individuals who have contracted the coronavirus and then recover. Knowledge and understanding of herd immunity are essential for the community to end the $\mathrm{C}-19$ pandemic. The $\mathrm{C}-19$ pandemic will terminate if the average herd immunity in a country is around $60 \%-70 \%$ of the entire population. Although vaccination can bring about herd immunity, it is still possible to contract the coronavirus with a milder impact, as shown in figure 1 . The fact that the coronavirus is in our lives despite being weakened needs further research or evolution. Society needs understanding regarding the inherent coronavirus condition around us and needs the role of counsellors. Counsellors can provide a deeper understanding of self-development to prevent the emergence of the C-19 pandemic again.

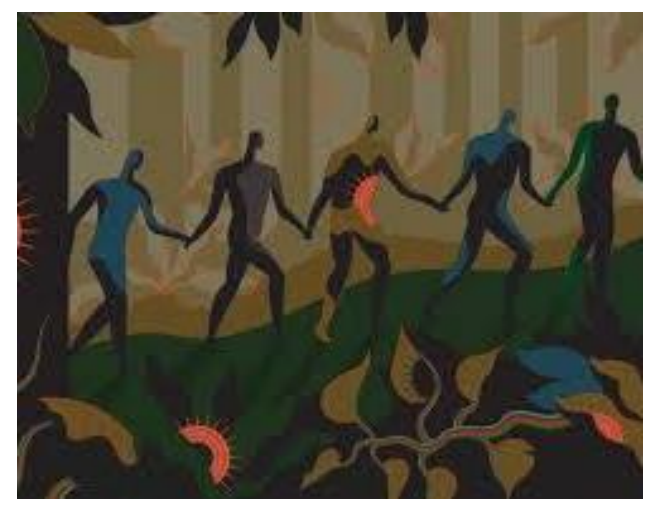

Figure 1. Community Herd Immunity in the C-19 pandemic condition or Post-C-19 Pandemic

The condition of herd immunity has obstacles, namely concerns and doubts about the vaccine so that it becomes an obstacle to the emergence of herd immunity. These conditions lead to delays and rejection of vaccines and delays in mass vaccinations, which impact the formation of herd immunity. Multi-sector involvement so that people believe in vaccines, as well as a confident approach to society. Counsellors also develop intentions, knowledge, beliefs, and motivations for vaccines, and empathy for vulnerable groups.

\section{Blended Counselling}

Intervention with blended counselling is a counselling strategy in the future $(\mathrm{C}-19$ pandemic condition and after the C-19 pandemic). The concepts of blended counselling need in-depth study with the aim of blended counselling. Details of the implementation of blended counselling require in-depth research to produce findings that are ready to be implemented.

Table 3. Blended counselling

\begin{tabular}{lll}
\multicolumn{1}{c}{ Topic } & \multicolumn{1}{c}{ Description } & \multicolumn{1}{c}{ Author } \\
\hline $\begin{array}{l}\text { Blended } \\
\text { counselling } \\
\text { concept }\end{array}$ & $\begin{array}{l}\text { Blended counselling is an integration of online and } \\
\text { offline counselling. }\end{array}$ & Pyrstöjärvi \& \\
Saramäki, (2011; \\
\hline
\end{tabular}




\begin{tabular}{|c|c|c|}
\hline Topic & Description & Author \\
\hline $\begin{array}{l}\text { The Purpose of } \\
\text { Blended } \\
\text { Counselling }\end{array}$ & $\begin{array}{l}\text { a. Blended counselling as a mediatization process to } \\
\text { ensure changes in the counselee or client. }\end{array}$ & $\begin{array}{l}\text { Engelhardt \& } \\
\text { Reindl, (2016); } \\
\text { Kondrup, (2013) }\end{array}$ \\
\hline $\begin{array}{l}\text { Implementation } \\
\text { of Blended } \\
\text { Counselling }\end{array}$ & $\begin{array}{l}\text { a. Blended counselling allows intensive and flexible } \\
\text { assistance. } \\
\text { b. Implementation of blended counselling using } \\
\text { supporting media, thus bringing up different aspects } \\
\text { in the counselling process. } \\
\text { c. Blended counselling uses technology in online } \\
\text { counselling services, then face-to-face counselling } \\
\text { implementation according to the conditions } \\
\text { determined together. } \\
\text { d. Blended counselling provides the mutual benefit of } \\
\text { data protection and counsellor competency } \\
\text { development. } \\
\text { The emphasis on blended counselling is adjusted to } \\
\text { the needs of the counselee or client regarding the } \\
\text { implementation of counselling (pure face-to-face or } \\
\text { pure virtual or face-to-face and face-to-face). }\end{array}$ & $\begin{array}{l}\text { Flammer et al., } \\
\text { (2018); Hörmann et } \\
\text { al., (2018); Rohr, } \\
(2020)\end{array}$ \\
\hline
\end{tabular}

The data concludes that blended counselling is a mixed counselling service that combines face-to-face and virtual. The combination is a process of meditation on changing clients or counselees. Blended counselling has flexibility and intensity in counselling services according to the time and condition of the counselee or client. Blended counselling requires support services through online media. The combination of online counselling services and face-to-face counselling still implements the principles of confidentiality and therapeutic relationships.

\section{Blended Counselling can Develop Mental Health and Understanding Herd Immunity}

Professional counsellors implement blended counselling. Blended counselling is a service that helps develop community mental health C-19 pandemic conditions and preparations for the post-C-19 pandemic. Mental health-based counselling services have a unique role in reducing the adverse effects of the pandemic as a supporter of individual recovery (Baldwin et al., 2021). The need for counselling services for mental health development is an urgency in the C-19 pandemic condition or preparation for the post-C-19 pandemic. Mental health service needs resilience training programs and stress reduction, job role changes, job recognition and communication, moral injury reduction strategies, peer and social support, and mental health support programs (Schwartz et al., 2020).

In addition to mental health, the public also needs clarity on the end of the C-19 pandemic. Can end a C-19 pandemic by controlling $\mathrm{C}-19$ by vaccination or non-pharmaceutical intervention, or called natural immunity (Microbe, 2021). Can complete a C-19 pandemic by establishing herd immunity through the participation of all elements of society. The cooperation of community elements makes a country in the world able to end the pandemic faster. Counsellors have a role in providing psychoeducation to the community, especially counselling services through face-to-face or virtual face-to-face. Counselling services aim to understand the importance of vaccination and herd immunity for the common good and the wider community. Understanding herd immunity is a central issue to end the war from the C19 pandemic. 
They blended counselling services as a relevant strategy that can apply to students, individuals with unique problems, communities, workers, and vulnerable people. The blended counselling service has advantages in flexibility and intensity because it combines online and face-to-face counselling services. The blended counselling service is different from only faceto-face services that require mutual agreement, especially the $\mathrm{C}-19$ pandemic conditions that have not ended and restrictions on face-to-face meetings. The study results found that remote intervention only resulted in improvements in three out of four people $(75 \%)$ related to problems C-19 pandemic condition. Families also needed space for face-to-face meetings (Yaffa et al., 2021). The results of other research related to online counselling support media such as asynchronous media with social media and synchronous media with virtual face-toface. Still, counsellors have limited use of technology (Supriyanto et al., 2020). These facts show the advantages of blended counselling as a flexible intervention in conditions of the C19 pandemic and dealing with post-C-19 situations to develop mental health and understand herd immunity in the community.

\section{Advantages of Blended Counseling over Face-to-Face Counseling or Virtual Counseling}

The flexibility of blended counselling is an advantage over face-to-face counselling, especially in individual mental development and community understanding of her immunity. The results showed no significant difference in satisfaction with face-to-face and virtual counselling (Murphy et al., 2009), and it is a fact that blended counselling is a tool that combines the two. Another assumption is that practitioners emphasize that counselling services must be face-to-face. However, research results emphasize that guidance and counselling practitioners must be ready to face the challenges of the digital era (Tait, 1999). This assumption reinforces that blended counselling is a digital era challenge strategy in counselling services, although it can also use face-to-face according to the counselee's needs.

The results of other studies show that cyber counselling is more satisfying to the counselee than face-to-face counselling (Zainudin \& Yusop, 2018). Cyber counselling is a form of flexibility in the digital era of counselling services, but not everyone has access to online counselling in the C-19 pandemic (Supriyanto et al., 2020). In addition to the flexibility from blended counselling, excess form blended counselling about the intensity with clients of the meeting customize client's condition. The client can choose by face-to-face or virtual. Blended counselling combines cyber or virtual counselling with face-to-face as a form of novelty in the digital era. It facilitates counsellors and counselees who need face-to-face counselling. Practitioners from psychotherapy, psychiatry, and counsellors must start blended counselling according to the needs of the current era, especially the development of mental health and the development of understanding herd immunity for the world community.

\section{Conclusions and Suggestions}

Problems society mental health due to economic complex problems. Disruption people conditions about mental health in the form of fear, anxiety, anger, insomnia, and prolonged stress. The end of the C-19 pandemic through the establishment of herd immunity. If the C-19 pandemic ends, mental health will emerge, and the community will be able to carry out activities as usual. The obstacle to the development of herd immunity is the public's concern and doubt about mass vaccination, resulting in the emergence of rejection or distrust of vaccines.

Significant role counsellors were informing mental health and the development of herd immunity through blended counselling-implementation of face-to-face or online or blended counselling. Blended counselling provides an opportunity for the community to be more flexible and intensive in the counselling service process. Practitioners, scientists, organizations, 
and the government can immediately apply blended counselling following the conditions of the C-19 pandemic and post-pandemic C-19 preparations as an intervention for the formation of mental health and the development of understanding herd immunity. This study is limited to counsellors' roles in implementing integrated counselling services to improve knowledge of herd immunity and mental health development. Still, it is undeniable that we can use blended counselling in other issues in the future. Blended counselling requires the joint efforts of various relevant organizations for the science and practice of psychotherapy, psychiatry, and counsellor.

\section{References}

Al-Amer, R., Maneze, D., Everett, B., Montayre, J., Villarosa, A. R., Dwekat, E., \& Salamonson, Y. (2021). COVID-19 vaccination intention in the first year of the pandemic: A systematic review. Journal of Clinical Nursing.

Alonzo, D., Popescu, M., \& Zubaroglu Ioannides, P. (2021). Mental health impact of the Covid-19 pandemic on parents in high-risk, low-income communities. International Journal of Social Psychiatry, 0020764021991896.

Baldwin, D. S., Gordon, R., \& Marlowe, K. (2021). The roles of a psychiatrist in the COVID19 pandemic. Clinics in Integrated Care, 100036.

Bank, W. (2020). The COVID-19 pandemic: Shocks to education and policy responses. World Bank.

Barker, P., Hartley, D., Beck, A. F., Oliver, G. "Holt," Sampath, B., Roderick, T., \& Miff, S. (2021). Rethinking Herd Immunity: Managing the Covid-19 Pandemic in a Dynamic Biological and Behavioral Environment. NEJM Catalyst Innovations in Care Delivery, 2(5).

Biondi, M., \& Iannitelli, A. (2020). CoViD-19 and stress in the pandemic:" sanity is not statistical". Rivista Di Psichiatria, 55(3), 1e-6e.

Bliss, C., Musikanski, L., Phillips, R., \& Davidson, L. (2021). When will the pandemic end? Suggestions for us communities to manage well-being in the face of COVID-19. International Journal of Community Well-Being, 4(3), 299-313.

Daniel, J. (2020). Education and the COVID-19 pandemic. Prospects, 49(1), 91-96.

Dassarma, B., Tripathy, S., Chabalala, M., \& Matsabisa, M. G. (2021). Challenges in Establishing Vaccine Induced Herd Immunity through Age Specific Community Vaccinations. Aging and Disease, 0.

Dhama, K., Sharun, K., Tiwari, R., Dhawan, M., Emran, T. B., Rabaan, A. A., \& Alhumaid, S. (2021). COVID-19 vaccine hesitancy-reasons and solutions to achieve a successful global vaccination campaign to tackle the ongoing pandemic. Human Vaccines \& Immunotherapeutics, 17(10), 3495-3499.

Engelhardt, E. M., \& Reindl, R. (2016). Blended Counseling-Beratungsform der Zukunft? Resonanzen-E-Journal Für Biopsychosoziale Dialoge in Psychosomatischer Medizin, Psychotherapie, Supervision Und Beratung, 4(2), 130-144. 
Flammer, P., Hörmann, M., Aeberhardt, D., \& Tschopp, D. (n.d.). Face-to-Face und mehr: Konzeption von Blended Counseling in der Suchtberatung. Aktuelle Forschungs-Und Entwicklungsprojekte Der Hochschule Für Soziale Arbeit FHNW, 6.

Garg, S., Singh, M. M., Deshmukh, C. P., Bhatnagar, N., Borle, A. L., \& Kumar, R. (2021). Critical interpretative synthesis of herd immunity for COVID-19 pandemic. Journal of Family Medicine and Primary Care, 10(3), 1117.

Gillard, S., Dare, C., Hardy, J., Nyikavaranda, P., Olive, R. R., Shah, P., Birken, M., Foye, U., Ocloo, J., \& Pearce, E. (2021). Experiences of living with mental health problems during the COVID-19 pandemic in the UK: A coproduced, participatory qualitative interview study. Social Psychiatry and Psychiatric Epidemiology, 1-11.

Grennan, D. (2019). What is a Pandemic? Jama, 321(9), 910-910.

Gumel, A. B., Iboi, E. A., Ngonghala, C. N., \& Ngwa, G. A. (2021). Towards achieving a vaccine-derived herd immunity threshold for Covid-19 in the US. MedRxiv, 2020-12.

Hildreth, J. E., \& Alcendor, D. J. (2021). Targeting Covid-19 Vaccine Hesitancy in Minority Populations in the US: Implications for Herd Immunity. Vaccines, 9(5), 489.

Holingue, C., Badillo-Goicoechea, E., Riehm, K. E., Veldhuis, C. B., Thrul, J., Johnson, R. M., Fallin, M. D., Kreuter, F., Stuart, E. A., \& Kalb, L. G. (2020). Mental distress during the COVID-19 pandemic among US adults without a pre-existing mental health condition: Findings from American trend panel survey. Preventive Medicine, 139, 106231.

Hörmann, M., Flammer, P., Tanner, A., Tschopp, D., \& Aeberhardt, D. (2018). Blended Counseling in der Suchtberatung. Suchtmagazin. Jg, 44, 21-26.

Johnson, S., Dalton-Locke, C., San Juan, N. V., Foye, U., Oram, S., Papamichail, A., Landau, S., Olive, R. R., Jeynes, T., \& Shah, P. (2021). Impact on mental health care and on mental health service users of the Covid-19 pandemic: A mixed methods survey of UK mental health care staff. Social Psychiatry and Psychiatric Epidemiology, 56(1), 2537.

Kondrup, S. (2013). Unskilled work and learner identity. 7th European Research Conference, 26.

Kopelovich, S. L., Monroe-DeVita, M., Buck, B. E., Brenner, C., Moser, L., Jarskog, L. F., Harker, S., \& Chwastiak, L. A. (2021). Community mental health care delivery during the Covid-19 pandemic: Practical strategies for improving care for people with serious mental illness. Community Mental Health Journal, 57(3), 405-415.

Krishnamurthy, S. (2020). The future of business education: A commentary in the shadow of the Covid-19 pandemic. Journal of Business Research, 117, 1-5.

Kumar, A., \& Nayar, K. R. (2021). Covid 19 and its mental health consequences. Taylor \& Francis.

Lestari, R., \& Setyawan, F. E. B. (2021). Mental health policy: Protecting community mental health during the Covid-19 pandemic. Journal of Public Health Research, 10(2). 
Li, F., Luo, S., Mu, W., Li, Y., Ye, L., Zheng, X., Xu, B., Ding, Y., Ling, P., \& Zhou, M. (2021). Effects of sources of social support and resilience on the mental health of different age groups during the Covid-19 pandemic. BMC Psychiatry, 21(1), 1-14.

MacIntyre, C. R., Costantino, V., \& Trent, M. (2021). Modelling of Covid-19 vaccination strategies and herd immunity, in scenarios of limited and full vaccine supply in NSW, Australia. Vaccine.

Marelli, S., Castelnuovo, A., Somma, A., Castronovo, V., Mombelli, S., Bottoni, D., Leitner, C., Fossati, A., \& Ferini-Strambi, L. (2021). Impact of Covid-19 lockdown on sleep quality in university students and administration staff. Journal of Neurology, 268(1), $8-15$.

Microbe, T. L. (2021). Covid-19 vaccines: The pandemic will not end overnight. The Lancet. Microbe, 2(1), e1.

Mukherjee, A., Bandopadhyay, G., \& Chatterjee, S. S. (2021). Covid-19 pandemic: Mental health and beyond-the Indian perspective. Irish Journal of Psychological Medicine, $38(2), 140-144$.

Murphy, L., Parnass, P., Mitchell, D. L., Hallett, R., Cayley, P., \& Seagram, S. (2009). Client satisfaction and outcome comparisons of online and face-to-face counselling methods. British Journal of Social Work, 39(4), 627-640.

Nashruddin, N., \& Tanasy, N. (2021). School Policies on the Use of Android Devices in Students Learning Activities during the Covid-19 Pandemic Condition. Lembaran Ilmu Kependidikan, 50(1), 66-73.

Pennington, T. H. (2021). Herd immunity: Could it bring the Covid-19 pandemic to an end? Future Medicine.

Pfattheicher, S., Petersen, M. B., \& Böhm, R. (2021). Information about herd immunity through vaccination and empathy promote Covid-19 vaccination intentions. Health Psychology.

Pyrstöjärvi, T., \& Saramäki, T. (2011). Blended counselling a means of supporting students. University of Eastern Finland.

Rahman, M. M., Khan, S. J., Sakib, M. S., Chakma, S., Procheta, N. F., Mamun, Z. A., Arony, A., Rahman, F., \& Rahman, M. M. (2021). Assessing the psychological condition among general people of Bangladesh during Covid-19 pandemic. Journal of Human Behavior in the Social Environment, 31(1-4), 449-463.

Rains, L. S., Johnson, S., Barnett, P., Steare, T., Needle, J. J., Carr, S., Taylor, B. L., Bentivegna, F., Edbrooke-Childs, J., \& Scott, H. R. (2021). Early impacts of the Covid19 pandemic on mental health care and on people with mental health conditions: Framework synthesis of international experiences and responses. Social Psychiatry and Psychiatric Epidemiology, 56(1), 13-24.

Rashid, S., \& Yadav, S. S. (2020). Impact of Covid-19 pandemic on higher education and research. Indian Journal of Human Development, 14(2), 340-343. 
Rogers, F. H., \& Sabarwal, S. (2020). Covid-19 Pandemic: Shocks to Education and Policy Responses.

Rohr, B. (2020). Blended Counseling: Distanzberatung im Beratungsalltag am Übergang 1.

Roy, A., Singh, A. K., Mishra, S., Chinnadurai, A., Mitra, A., \& Bakshi, O. (2021). Mental health implications of Covid-19 pandemic and its response in India. The International Journal of Social Psychiatry, 67(5), 587.

Schaeffer, B., Taylor, B., Bushman, M., \& Hanage, W. P. (2021). The devil in the details: Herd immunity and pandemic response. Cell Host \& Microbe, 29(7), 1048-1051.

Schwartz, R., Sinskey, J. L., Anand, U., \& Margolis, R. D. (2020). Addressing postpandemic clinician mental health: A narrative review and conceptual framework. Annals of Internal Medicine, 173(12), 981-988.

Setiawan, F., Yudianto, A., Sunariani, J., \& Mooduto, L. (2021). New Normal to Achieve High Threshold Herd Immunity by (Ro and Pc) Post Pandemic Covid-19. Malaysian Journal of Medicine and Health Sciences, 17(2), 141-145.

Setiyowati, A. J., Pali, M., Wiyono, B. B., \& Triyono, T. (2019). Structural model of counseling competence. Jurnal Cakrawala Pendidikan, 38(1), 45-62.

Sonia, D., \& Kumar, R. (2020). Students' Perception towards Digitization of Education after Covid-19: A Survey. International Journal of Engineering, Science, 1(1).

Supriyanto, A., Hartini, S., Irdasari, W. N., Miftahul, A., Oktapiana, S., \& Mumpuni, S. D. (2020). Teacher professional quality: Counselling services with technology in Pandemic Covid-19. Counsellia: Jurnal Bimbingan Dan Konseling, 10(2), 176-189.

Tait, A. (1999). Face-to-face and at a distance: The mediation of guidance and counselling through the new technologies. British Journal of Guidance \& Counselling, 27(1), 113122.

Toquero, C. M. (2020). Challenges and opportunities for higher education amid the COVID19 pandemic: The Philippine context. Pedagogical Research, 5(4).

Van Tilburg, T. G., Steinmetz, S., Stolte, E., van der Roest, H., \& de Vries, D. H. (2021). Loneliness and mental health during the COVID-19 pandemic: A study among Dutch older adults. The Journals of Gerontology: Series B, 76(7), e249-e255.

Weiá, S. (2013). Blended Counseling: Zielorientierte Integration der Off-und Onlineberatung. Diplomica Verlag.

Wiysonge, C. S., Ndwandwe, D., Ryan, J., Jaca, A., Batouré, O., Anya, B.-P. M., \& Cooper, S. (2021). Vaccine hesitancy in the era of Covid-19: Could lessons from the past help in divining the future? Human Vaccines \& Immunotherapeutics, 1-3.

Xia, Y., Zhong, L., Tan, J., Zhang, Z., Lyu, J., Chen, Y., Zhao, A., Huang, L., Long, Z., \& Liu, N.-N. (2020). How to understand "herd immunity" in Covid-19 pandemic. Frontiers in Cell and Developmental Biology, 8, 991. 
Yaffa, S., Adi, E.-L., Itai, P., Marit, J.-M., Doron, G., \& Daniel, S. (2021). Treatment of eating disorders in adolescents during the Covid-19 pandemic: A case series. Journal of Eating Disorders, 9(1), 1-11.

Zaidi, S., Rizwan, F., Riaz, Q., Siddiqui, A., Khawaja, S., Imam, M., Naz, A., Waheed, S., \& Shamsi, T. (2021). Seroprevalence of anti-SARS-CoV-2 antibodies in residents of Karachi-Challenges in acquiring herd immunity for Covid 19. Journal of Public Health, 43(1), 3-8.

Zainudin, Z. N., \& Yusop, Y. M. (2018). Client's satisfaction in face-to-face counselling and cyber counseling approaches: A comparison. International Journal of Academic Research in Business and Social Sciences, 8(3), 677-684. 